\title{
New Zealand Corporate Boards in Transition: Composition, Activity and Incentives Between 1995 and 2010*
}

\author{
Glenn Boyle ${ }^{\dagger}$ \\ Department of Economics and Finance \\ University of Canterbury \\ Xu (Jane) Ji \\ Department of Economics and Finance \\ University of Canterbury
}

November 24, 2011

*For helpful comments on earlier versions of this paper, we are grateful to Mike Bradbury, Neil Crombie, Helen Roberts, Alan Stent, and to workshop participants at the University of Canterbury and the NZ Shareholders Association (Christchurch branch). Scott Rademaker provided invaluable research assistance. Any remaining errors or ambiguities are solely our responsibility.

$\dagger$ Corresponding author: Private Bag 4800, Christchurch 8140, New Zealand. Phone: 64-3-364-3479; Fax 64-3-364-2635. Email: glenn.boyle@canterbury.ac.nz 


\title{
New Zealand Corporate Boards in Transition: Composition, Activity and Incentives Between 1995 and 2010
}

\begin{abstract}
We document, describe and interpret changes in New Zealand corporate board characteristics between 1995 and 2010, a period centred around the 2003 introduction of the NZX Corporate Governance Best Practice Code. Unsurprisingly, the representation of non-executive, independent and female directors on NZ boards rose during the period, as did real chair and director fees and the importance of board committees, while average board size fell. Perhaps more surprisingly, much of this movement occurred before 2003. However, the magnitude of these changes frequently varies according to firm size, and there are some intriguing differences between New Zealand board characteristics and those prevailing in other, larger, countries. We use this information to identify a number of unanswered questions about New Zealand corporate boards.
\end{abstract}

JEL classification: G34, G38

Keywords: corporate governance, board of directors; board structure 


\section{New Zealand Corporate Boards in Transition: Composition, Activity and Incentives Between 1995 and 2010}

\section{Introduction}

Over the last 25 years, the role of corporate governance in determining firm performance has been extensively discussed and examined by researchers, journalists, corporate officers, regulators and politicians. As a result of this focus, many countries - including Australia, Canada, France, Germany, Hong Kong, Japan, New Zealand, Singapore, Sweden, the United Kingdom (UK) and the United States (US) - have adopted corporate governance guidelines or codes that are intended to encourage or require firms to adopt so-called 'best-practice' models of governance. ${ }^{1}$

Underpinning this legislative activity is a voluminous amount of academic research: Adams et al. (2010), Becht et al. (2003), Clarke (2007), Gillan (2006) and Leblanc and Gillies (2005) provide excellent summaries of the various strands of the international literature. In New Zealand (NZ), governance research has focused almost exclusively on a subset of what Gillan calls 'internal governance': the role and activities of the board of directors. For example, many authors attempt to determine the importance of a limited number of board characteristics (usually board size and the prevalence of outside directors) for NZ firm performance, e.g., Chin et al. (2004), Elayan et al. (2003), Hossain et al. (2001), Prevost et al. (2002), Reddy et al. (2008), and Reddy et al. (2010). Others examine the relationship between board characteristics and (i) executive compensation (e.g., Andjelkovic et al., 2002; Hurst and Vos, 2009; Jiang et al., 2009) or (ii) firm derivatives usage (Marsden and Prevost, 2005) or (iii) financial reporting quality (Rainsbury et al., 2009). ${ }^{2}$ A much smaller body of work investigates the determinants of the board characteristics themselves. For example, Cahan and Wilkinson (1999) examine the impact of the 1993 Companies Act on outside director representation, while Mak and Roush (2000) use 1980s IPO data to identify systematic variation in board size, outside director representation, and the prevalence of CEOs who also act as board chairs. Similarly, Rainsbury et al. (2008) document the relationship between voluntary adoption of an audit committee and other board characteristics.

In all of these studies, information on NZ boards is essentially treated as a means to an end - either as a set of exogenous variables potentially explaining outcomes of interest such as firm performance or executive compensation, or as endogenous variables

\footnotetext{
${ }^{1}$ The New Zealand Corporate Governance Best Practice Code was developed and released by the stock exchange (NZX) in 2003. It was subsequently adopted by the New Zealand Securities Commission as a set of guidelines for all NZ firms, while parts of it were incorporated in the NZX listing rules.

${ }^{2}$ In addition, Cahan et al. (2005) investigate the relationship between board structure and CEO pay in state-owned enterprises.
} 
whose within-NZ variation is to be explained - rather than being of intrinsic interest. ${ }^{3}$ Moreover, these studies are necessarily limited in scope: information is provided about only a very small number of board characteristics, different authors use different definitions or measurements of these variables, and the sample periods tend to be concentrated in the 1980s and 1990s. As a result, we have only a very rough idea of the overall state and evolution of NZ boards - what one might call the 'stylised facts' of NZ internal governance.

In this paper, we seek to fill this gap by documenting the composition, activity and incentives of NZ boards during the 15-year period between 1995 and 2010. We examine the extent to which these features have changed over time, how both their levels and trends compare with other countries, and their relationship with firm size. Such a task is potentially important as virtually all existing research on board structure focuses on firms from large economies, particularly the US and UK. By contrast, relatively little is known about the internal governance of firms in small, open economies. In addition, because the 1995-2010 time period is conveniently centred around the 2003 introduction of the NZX Corporate Governance Best Practice Code, we are able to provide some preliminary assessments of the impact of this initiative. Perhaps most importantly, we identify a number of unanswered questions and puzzles that may well serve as a useful agenda for future NZ-based governance research.

In the next section, we describe our data and the 22 board characteristics that are the focus of this paper. Section 3 begins by comparing the situation in 2010 with that of 1995: this allows us to see which board features have changed and which have not, and to make some simple comparisons with other countries. We also illustrate and discuss trends in selected variables over the entire sample period. In section 4, we (i) investigate whether these trends differ according to firm size, (ii) compare the board characteristics of singlelisted NZX firms with those that also list on the Australian exchange, and (iii) determine whether board characteristics have become more or less dispersed during our sample period. Finally, in section 5 , we summarise the possible research questions uncovered by our analysis and offer some concluding remarks.

\section{Variables and Data}

\subsection{Variables}

A full list (and accompanying description) of the variables analysed in this paper appears in Table 1. In the rest of this section, we provide a brief discussion of the theory underlying, and evidence associated with, each of these variables.

\footnotetext{
${ }^{3}$ An exception is Fox (1996) who describes the 1980-1993 evolution of NZ boards. However, his sample period mainly pre-dates the resurgence of interest in governance matters and, moreover, he considers only a very small number (four) of board characteristics - largely reflecting the data that were readily available at that time.
} 
Table 1: Definition of Variables

Description and definition of the variables analysed in this study.

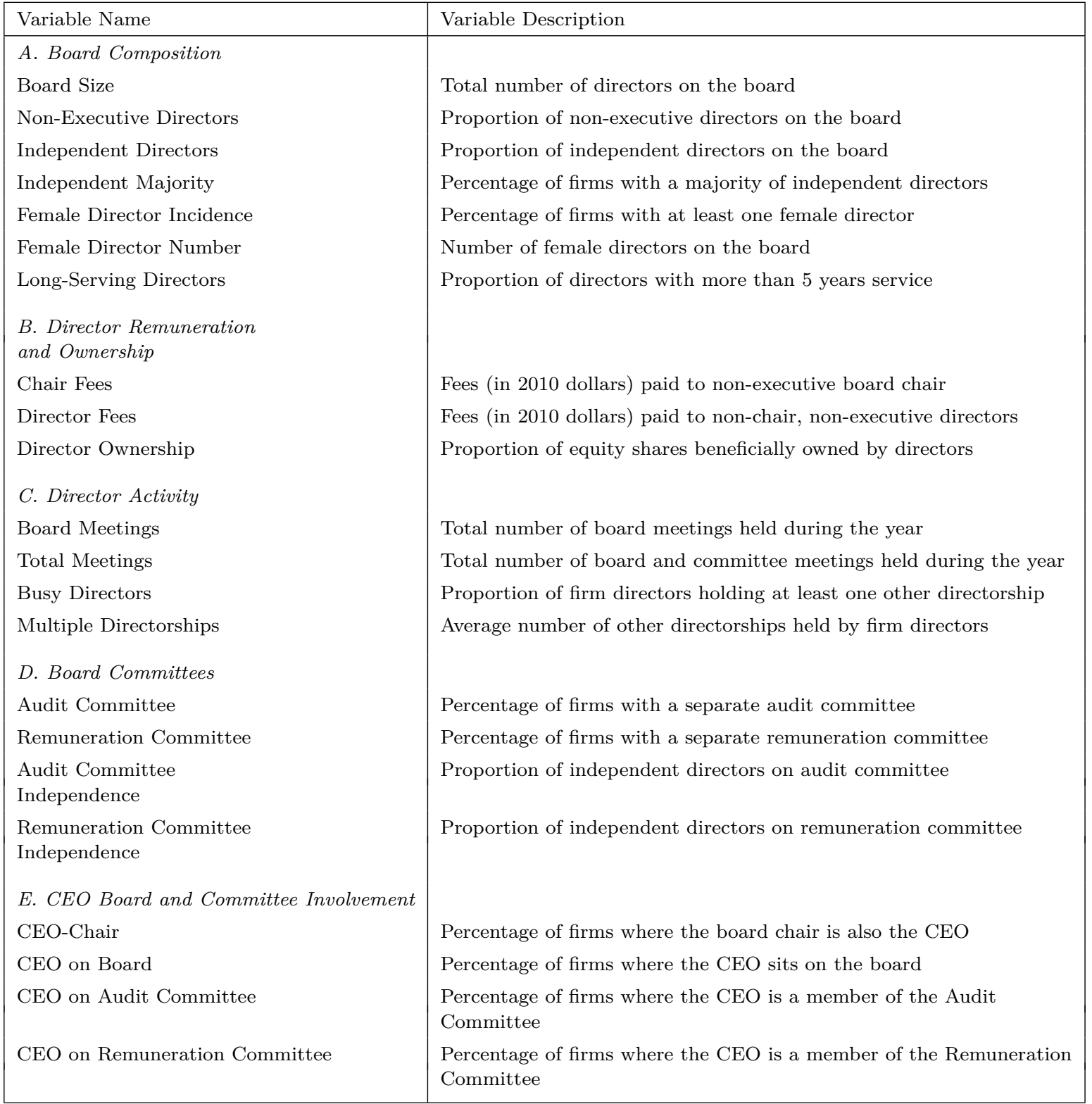




\subsubsection{Board composition}

Board with a greater number of directors can potentially call on a wider range of expertise. However, large boards also have disadvantages: individual director responsibility is weakened (a 'safety-in-numbers' effect), and greater difficulties in co-ordinating effective discussion can lead to a dilution of decision-making power with consequent domination by the CEO. Unsurprisingly, therefore, evidence on the importance of board size is mixed. Yermack (1996), Guest (2009) and Mak and Kusndadi (2005) report a negative relationship between board size and firm performance for US, UK and Asian firms respectively. However, for US firms, Coles et al. (2007) find that the link depends on firm type - the relationship is negative for simple firms, but positive for complex firms (which have greater need of wider expertise). In NZ, Chin et al. (2004) and Reddy et al. (2010) report no relationship between firm size and board performance; Andjelkovic et al. (2002) and Hurst and Vos (2007) similarly find no link between board size and CEO remuneration.

By being less beholden to the CEO, non-executive and independent directors can potentially enhance oversight and monitoring of firm activities (Fama and Jensen, 1983). On the other hand, such directors are often less familiar with the industry in which their firm operates. Consistent with these contrasting views, some authors (e.g., Byrd and Hickman, 1992; Dann et al., 2003; Ryan and Wiggins, 2004) find that greater board independence has a positive effect on various aspects of firm performance, while others (e.g., Agrawal and Knoeber, 1996; Barnhart and Rosentein, 1998; Bhagat and Black, 2002) find the reverse, at least for some firm types. In NZ, NZX Listing Rule 3.3.1 requires that a minimum proportion of board directors be independent. ${ }^{4}$ Reassuringly, therefore, NZ studies generally report a positive relationship between the percentage of outside and/or independent directors and Tobin's Q, e.g., Hossain et al. (2001), Reddy et al. (2008) and Reddy et al. (2010).

Greater female representation on boards not only increases the size of the human capital pool from which directors can be drawn, but also provides some additional skills and perspectives that may not be possible with all-male boards. In recent years, both Norway and France have imposed quotas for female representation. Providing some support for such actions, Adams and Ferreira (2009) find that more gender-diverse boards are tougher monitors. However, they also note that this attribute only seems to be valuable in firms with weak shareholder rights, and that the overall relationship between firm performance and female representation on boards is negative. Although there appears to be no NZ evidence on the effectiveness of female directors, there is a regular stream of media comment suggesting that NZ firms are laggards when it comes to appointing female

\footnotetext{
${ }^{4} \mathrm{An}$ independent director is one who is not an executive of the firm and who has no disqualifying relationship. In practice, this is generally interpreted to mean that an independent director owns less than $5 \%$ of the firm's shares and receives less than $10 \%$ of his annual income from the firm. This is the definition we use for identifying independent directors in years before the NZX listing rules required firms to list independent directors in their annual reports.
} 
directors. ${ }^{5}$ We measure female board representation in two ways: the percentage of firms with at least one female director, and the number of female directors per board.

Finally on board composition, long-serving directors bring experience and commitment to the boardroom table, but also greater 'familiarity' with management that can weaken oversight and monitoring. Vafeas (2003) reports results consistent with the latter view, suggesting that lengthy board tenure is often associated with directors who befriend management at the expense of shareholders. NZX Listing Rules 3.3.9 and 3.3.11 specify a 5-year maximum term of appointment for executive directors and a 1/3 minimum of directors to retire each year (although reappointment is allowed in both cases). We define a long-serving director as one with more than five years continuous service on the board.

\subsubsection{Director Remuneration and Ownership}

Although typically only a tiny proportion of firm income, there is some evidence that directors' fees are positively linked to CEO remuneration ('cronyism') and that this has an adverse impact on firm performance, e.g., Brick et al. (2006). An alternative mechanism for incentivising and compensating directors is via director share ownership that directly aligns directors' interests with those of shareholders, although too great an ownership share can put directors in conflict with small shareholders. Bhagat and Bolton (2010) and Bhagat et al. (1999) both find a positive impact of director share ownership on US firm performance as do, albeit somewhat less strongly, Farrer and Ramsay (1998) for Australian firms.

NZ has no specific restrictions on director remuneration or share ownership, although the NZX Best Practice Code recommends that directors take a portion of their remuneration in the form of non-vested shares. We include only beneficially-owned shares in our measure of director ownership.

\subsubsection{Director Activity}

The most visible way in which directors fulfill their responsibilities is via attendance at board and committee meetings. On the one hand, a greater number of meetings may indicate more diligent boards; on the other it may simply reflect the substitution of formfilling activities for true diligence. Interestingly, Vafeas (1999) reports that the annual number of board meetings is negatively related to firm value, but also notes that this result is driven by an increase in board activity following share price falls. Once this latter effect is controlled for, Brick and Chidambaran (2010) find that firms holding more board and committee meetings tend to have greater value.

Many directors hold directorships at more than one firm. While the holding of multiple directorships can provide valuable experience and indicate high director quality, it also raises the potential for workload problems that diminish overall effectiveness. Neither Ferris et al. (2003) nor Sarkar and Sarkar (2009) find any evidence of shirking by 'busy'

\footnotetext{
${ }^{5}$ See, for example, Radio NZ (2011)
} 
directors, but Fich and Shivdasani (2006) conclude that firms with a majority of busy outside directors are weaker performers on average. We employ two measures of director busyness: the proportion of board members holding at least one other directorship, and the average number of other directorships held by board members.

\subsubsection{Board Committees}

The formation of board committees allows specialist oversight of sensitive areas. Authors such as Anderson and Bizjak (2003), Bradbury et al. (2006), Brick and Chidambaran (2010), Klein (2002) and Zhang et al. (2007) examine the importance of the audit and/or remuneration committees for various firm activities. NZX Listing Rules 3.6.1 and 3.6.2 require NZ firms listed on the main board to have an audit committee containing a majority of independent directors. The Best Practice Code contains similar recommendations regarding remuneration committees. We investigate the extent of both audit and remuneration committee existence and independence in NZ firms.

\subsubsection{CEO Involvement}

The final characteristic we analyse is the involvement of CEOs in board and committee activities. CEO participation in board discussions and decision-making can facilitate effective communication and motivate CEOs (e.g., Brickley at al., 1997; Muth and Donaldson, 1998), but may also be associated with significant agency problems (e.g., Bebchuck and Fried, 2004; Fama and Jensen, 1983). Apparently persuaded by the latter view, the NZX Best Practice Code recommends that the CEO should not fill the role of board chair, nor sit on the audit committee.

\subsection{Data}

The principal source of our data is the NZX Deep Archive annual reports collection. We begin by identifying all NZX-listed firms for which an annual report is available in 1995 and then eliminate those firms which are not NZ-registered, or whose primary listing exchange is in another country, or whose annual report contains no useful data. For example, there are a total of 99 firm-reports available for 1995, but 11 of these are from overseas firms and two others contain no useful data, leaving a total of 86 firms available for analysis. For each of these firms, we collect all available data for the variables listed in Table 1. We then repeat this exercise for each of 2000, 2007 and 2010. We use 1995 as our starting year as this is the first year in which the increased disclosure requirements of the 1993 Companies Act began to take effect. Prior to that time, NZ company annual reports often contained little information about board activities, so beginning our sample period before 1995 would, therefore, have resulted in very small sample sizes for some variables.

Where information on director identity, outside directorships, and tenure is not 
Table 2: Sample Descriptive Statistics

Summary descriptive statistics on sample and firm size. Small firms have total assets equal to less than $\$ 50$ million (in 2010 dollars); medium firms have total assets between $\$ 50$ million and $\$ 250$ million; large firms have total assets greater than $\$ 250$ million.

\begin{tabular}{|c|c|c|c|c|c|}
\hline Variable & & All & Small & Medium & Large \\
\hline \multicolumn{6}{|l|}{ Number of Firms } \\
\hline 1995 & & 86 & 26 & 34 & 26 \\
\hline 2000 & & 102 & 21 & 39 & 42 \\
\hline 2007 & & 134 & 58 & 34 & 42 \\
\hline 2010 & & 117 & 43 & 37 & 37 \\
\hline \multicolumn{6}{|c|}{ Mean Firm Size (2010 \$million) } \\
\hline 1995 & & 644.36 & 18.801 & 120.09 & 1955.5 \\
\hline 2000 & & 833.74 & 22.073 & 128.09 & 1894.8 \\
\hline 2007 & & 864.93 & 19.076 & 135.87 & 1676.6 \\
\hline 2010 & & 565.55 & 16.099 & 141.27 & 1628.4 \\
\hline \multicolumn{6}{|c|}{ Median Firm Size (2010 \$million) } \\
\hline 1995 & & 94.840 & 15.909 & 94.840 & 728.24 \\
\hline 2000 & & 168.57 & 16.198 & 122.90 & 573.18 \\
\hline 2007 & & 98.43 & 17.122 & 133.91 & 694.04 \\
\hline 2010 & & 113.49 & 8.2724 & 126.95 & 719.30 \\
\hline
\end{tabular}

recorded in an annual report, we turn to the NZ Companies Office website. ${ }^{6}$ This contains a searchable archive of information on all NZ-registered firms and their directors, thereby allowing us to fill gaps in the annual reports. However, because director information is available only on an individual basis, this is a very time-intensive solution. ${ }^{7}$

Finally, to ensure comparability across time, we express all monetary values in 2010 NZ dollars. For this purpose, we adjust non-2010 values by the appropriate percentage increase in the NZ consumer price index, which can be obtained from the Reserve Bank of NZ website. ${ }^{8}$

Table 2 provides some summary information about our sample, which contains 86 firms for 1995, 102 for 2000, 134 for 2007, and 117 for 2010. Mean firm size is greater in the earlier years (reflecting in part the delisting of large firms like Carter Holt Harvey and Lion Nathan during the period), but median size is greater at the end of the sample period than the beginning.

We also split our sample into three somewhat arbitrary size groups: small (total assets less than $\$ 50$ million in 2010 dollars), medium (total assets between $\$ 50$ million and $\$ 250$ million), and large (total assets greater than $\$ 250$ million). As can be seen in Table 2 , these categories divide the total number of companies up roughly equally in each sample year, although 1995 and 2000 have relatively large proportions of firms in the medium-size

\footnotetext{
${ }^{6}$ See http://www.business.govt.nz/companies/

${ }^{7}$ For other variables, we were sometimes able to obtain additional information from the company's website.

${ }^{8}$ See http://www.rbnz.govt.nz/statistics/az/2989609.html
} 
group while small firms predominate in the latter years.

\section{$3 \quad$ Primary Analysis and Results}

To obtain an overall picture of what has occurred over the 15-year period, we begin by focussing on the differences between the bookend years of 1995 and 2010; a subsequent section examines trends revealed by the intermediate years. We assume our data for 1995 and 2010 provide representative samples of an underlying (hypothetical) population of NZ firms during their respective years, thus allowing us to calculate some simple distributional statistics for each of the variables appearing in Table 1. For the continuous variables, we estimate means and medians and test for 1995-2010 differences using $t$ - and Wilcoxontests respectively. For binary variables, we report the percentage of firms having this characteristic and test for 1995-2010 differences using a binomial z-test. In case these simple statistics are a function of firm size, we also regress each board characteristic on firm size (in 2010 dollars) and a sample-year dummy, and report the significance of the heteroskedasticity-robust $t$-statistic associated with the latter. We also use these estimates to shed some light on the similarities and differences between NZ boards and those from other countries; for this purpose we focus on countries which also follow the Anglo-European model of governance, primarily based on agency theory, e.g., Australia, the UK, and the US.

\subsection{Differences between 1995 and 2010}

\subsubsection{Board composition}

Table 3 reveals that average board size fell from about 6.6 directors in 1995 to 5.9 in 2010 , and that this decline is significant at the $1 \%$ level even after controlling for firm size. At the same time, the representation of independent and, less clearly, non-executive directors rose significantly to the point where on average they comprise approximately $2 / 3$ and $4 / 5$ respectively of boards in 2010. Moreover, the percentage of boards with a majority of independent directors increased by 17 percentage points (46\% to $63 \%$ ). ${ }^{9}$ Female representation on boards also rose substantially: the percentage of boards with at least one female director more than tripled during the 15-year period covered by our sample, as did the average number of female directors per board (albeit to a still rather low 0.5 , with a median of zero). Director tenure also saw a significant increase, with directors having more than five years service now in the majority at the average firm.

All of these trends are broadly in line with the experience of other countries internationally, boards have attempted to "do more with less" and place more emphasis on board independence. For example, Chhaochharia and Grinstein (2007) report similar

\footnotetext{
${ }^{9}$ Note, however, that prior to $2003 \mathrm{NZ}$ firms were not required to distinguish between independent and non-independent directors. Consequently, 1995 director independence is based in our own assessment of who was independent and who wasn't, and may therefore contain considerable error.
} 
Table 3: Board Composition

Comparison of 1995 and 2010 statistics for board composition. Variable definitions and sample sizes appear in Table 1. Terms in parentheses underneath the variable names indicate the sample sizes for 1995 and 2010 respectively. The $t$-test is used to evaluate differences in sample means; the W (Wilcoxon)-test is used to evaluate differences in sample medians; the Binomial test is based on a $z$-statistic and is used to evaluate differences in sample proportions; the Size-adjusted $t$-test extends the standard $t$ and Binomial tests by controlling for firm size in an OLS regression. ${ }^{* * *}\left({ }^{* *}\right)\left({ }^{*}\right)$ denotes statistical significance at the $1 \%(5 \%)$ (10\%) level.

\begin{tabular}{|c|c|c|c|c|c|}
\hline Variable & $\begin{array}{c}1995 \\
\text { Mean or \% } \\
\text { (Median) }\end{array}$ & $\begin{array}{c}2010 \\
\text { Mean or \% } \\
\text { (Median) }\end{array}$ & $\begin{array}{c}t \text {-test } \\
(\mathrm{W} \text {-test })\end{array}$ & $\begin{array}{l}\text { Binomial } \\
\text { test }\end{array}$ & $\begin{array}{l}\text { Size-adjusted } \\
t \text {-test }\end{array}$ \\
\hline $\begin{array}{l}\text { Board Size } \\
(86,117)\end{array}$ & $\begin{array}{c}6.605 \\
(6.000)\end{array}$ & $\begin{array}{c}5.872 \\
(6.000)\end{array}$ & $\begin{array}{c}* * * \\
(* * *)\end{array}$ & & $* * *$ \\
\hline $\begin{array}{l}\text { Non-Executive Directors } \\
(86,117)\end{array}$ & $\begin{array}{c}0.784 \\
(0.833)\end{array}$ & $\begin{array}{c}0.834 \\
(0.833)\end{array}$ & $*$ & & $* *$ \\
\hline $\begin{array}{l}\text { Independent Directors } \\
(59,115)\end{array}$ & $\begin{array}{c}0.555 \\
(0.500)\end{array}$ & $\begin{array}{c}0.627 \\
(0.667)\end{array}$ & $\begin{array}{c}* * \\
(* *)\end{array}$ & & $* *$ \\
\hline $\begin{array}{l}\text { Independent Majority } \\
(59,115)\end{array}$ & $45.8 \%$ & $62.6 \%$ & & $* *$ & $* *$ \\
\hline $\begin{array}{l}\text { Female Director Incidence } \\
(86,117)\end{array}$ & $11.6 \%$ & $34.2 \%$ & & $* * *$ & $* * *$ \\
\hline $\begin{array}{l}\text { Female Director Number } \\
(86,117)\end{array}$ & $\begin{array}{c}0.140 \\
(0.000)\end{array}$ & $\begin{array}{c}0.479 \\
(0.000)\end{array}$ & $\begin{array}{c}* * * \\
(* * *)\end{array}$ & & $* * *$ \\
\hline $\begin{array}{l}\text { Long-Serving Directors } \\
(86,117)\end{array}$ & $\begin{array}{c}0.335 \\
(0.333)\end{array}$ & $\begin{array}{c}0.555 \\
(0.600)\end{array}$ & $\begin{array}{c}* * * \\
(* * *)\end{array}$ & & $* * *$ \\
\hline
\end{tabular}

proportional changes in the size and independence of US boards between 1997 and 2003, as do Simpson et al. (2010) for female representation. In the same vein, the data of Kesner (1988) and Van Ness et al. (2010) imply a mean increase in US director tenure of approximately $10 \%$ ( 7.2 years to 7.9 years).

Turning to international differences in levels, evidence from the US (Chhaochharia and Grinstein, 2007; Ning et al., 2010), UK (Guest, 2009), and Australia (Kang et al., 2007 ) indicates that board size is noticeably smaller in NZ, but this almost certainly reflects the smaller size of NZ firms. More interestingly, independent director representation in NZ is somewhat lower than elsewhere. For example, Chhaochharia and Grinstein estimate the mean representation of independent directors on US boards in 2003 to be $71.4 \%$ while Kang et al. report that $83 \%$ of their sample of Australian firms in 2003 have an independent director majority. Turning to female representation, Table 3 implies that females hold approximately $8.2 \%$ of NZ directorships in 2010, somewhat lower than Adams and Ferreira (2009) and Simpson et al. (2010) find for the US (8.9\% for 1995-2003 and 11.9\% in 2007 respectively) and Kang et al. (2007) report for Australia (10.37\% in 2003), but somewhat higher than Francoeur et al. (2007) estimate for Canada (7.02\% in 2001-03). 
Table 4: Director Remuneration and Ownership

Comparison of 1995 and 2010 statistics for director remuneration and ownership. Variable definitions and sample sizes appear in Table 1. Terms in parentheses underneath the variable names indicate the sample sizes for 1995 and 2010 respectively. The $t$-test is used to evaluate differences in sample means; the W (Wilcoxon)-test is used to evaluate differences in sample medians; the Size-adjusted $t$-test extends the standard $t$-test by controlling for firm size in an OLS regression. ${ }^{* * *}\left({ }^{* *}\right)\left({ }^{*}\right)$ denotes statistical significance at the $1 \%(5 \%)(10 \%)$ level.

\begin{tabular}{lcccc}
\hline & 1995 & 2010 & & \\
Variable & $\begin{array}{c}\text { Mean } \\
\text { Median })\end{array}$ & $\begin{array}{c}\text { Mean } \\
\text { (Median) }\end{array}$ & $\begin{array}{c}t \text {-test } \\
(\text { W-test })\end{array}$ & $\begin{array}{c}\text { Size-adjusted } \\
t \text {-test }\end{array}$ \\
\hline Chair Fees & 51889 & 86604 & $* * *$ & $* * *$ \\
$(30,111)$ & $(46003)$ & $(70000)$ & $(* * *)$ & $* * *$ \\
$\begin{array}{l}\text { Director Fees } \\
(32,117)\end{array}$ & 29913 & 48787 & $* * *$ & \\
$\begin{array}{l}\text { Director Ownership } \\
(69,117)\end{array}$ & 0.031 & 0.023 & & \\
\hline \hline
\end{tabular}

\subsubsection{Director Remuneration and Ownership}

As can be seen in Table 4, fees paid to board chairs and directors increased by more than $60 \%$ in real terms between 1995 and 2010. By way of comparison, the corresponding change in the all-sector Labour Cost Index over the same period was 1.5\%. Clearly, director remuneration increased at a much faster rate than overall wages and salaries.

During the same period, director share ownership moved in the reverse direction, with median board ownership per director equalling 0.5\% of firm shares in 1995 and $0.3 \%$ in 2010. Although the difference is statistically insignificant at conventional levels, this change is nevertheless surprising given the NZX Best Practice Code recommendation for share remuneration of directors.

Despite its rapid rise over the 15-year sample period, NZ director remuneration remains fairly low compared to countries such as Australia (e.g., Henry, 2010) and the US (e.g., Adams and Ferreira, 2009; Cordeiro et al., 2000; Linn and Park, 2005), among others, although much of this differential is likely to be due to the smaller size of NZ firms. Turning to director share ownership, the NZ figures are similar to those obtained for Australia by Honeine and Swan (2010), but almost an order of magnitude higher than the approximate $0.05 \%$ ownership stake reported by Chhaochharia and Grinstein (2007) and Bhagat and Bolton (2010) for the the typical US director. Such a difference is unsurprising given the much greater size and value of US firms.

\subsubsection{Director Activity}

Apart from some weak evidence for a small decline in board meeting frequency, Table 5 reveals that overall board activity remained largely unchanged over the sample period: board meetings take place approximately 11 times a year and each director holds approximately 8 directorships. This number of board meetings is high compared to the 7-8 annual 
Table 5: Director Activity

Comparison of 1995 and 2010 statistics for director remuneration and ownership. Variable definitions and sample sizes appear in Table 1. Terms in parentheses underneath the variable names indicate the sample sizes for 1995 and 2010 respectively. The $t$-test is used to evaluate differences in sample means; the W (Wilcoxon)-test is used to evaluate differences in sample medians; the Size-adjusted $t$-test extends the standard $t$-test by controlling for firm size in an OLS regression. ${ }^{* * *}\left({ }^{* *}\right)\left({ }^{*}\right)$ denotes statistical significance at the $1 \%(5 \%)(10 \%)$ level.

\begin{tabular}{lcccc}
\hline & 1995 & 2010 & & \\
Variable & $\begin{array}{c}\text { Mean } \\
\text { (Median) }\end{array}$ & $\begin{array}{c}\text { Mean } \\
(\text { Median })\end{array}$ & $\begin{array}{c}t \text {-test } \\
(\text { W-test })\end{array}$ & $\begin{array}{c}\text { Size-adjusted } \\
t \text {-test }\end{array}$ \\
\hline Board Meetings & 11.12 & 10.88 & & \\
$(34,80)$ & $(11.00)$ & $(10.00)$ & $\left({ }^{*}\right)$ & \\
Total Meetings & 13.70 & 15.05 & & \\
$(34,80)$ & $(14.00)$ & $(13.50)$ & \\
Busy Directors & 0.868 & 0.883 & \\
$(86,117)$ & $(0.889)$ & $(1.000)$ & \\
Multiple Directorships & 8.584 & 7.644 & \\
$(86,117)$ & $(6.111)$ & $(6.250)$ & \\
\hline \hline
\end{tabular}

meetings reported by Al-Najjar (2010) and Brick and Chidambaran (2010) for UK and US firms respectively. Similarly, NZ directors appear to take on a large number of other directorships compared to their overseas counterparts: Chhaochharia and Grinstein (2007) and Ferris et al. (2003) find that the typical US director holds fewer than two directorships and Kiel and Nicholson (2006) report a similar workload for Australian directors. However, this latter difference is almost certainly over-stated - the above authors count only directorships in listed companies, whereas the Table 5 figures also include directorships in unlisted firms. ${ }^{10}$

\subsubsection{Board Committees}

Table 6 shows the increased prominence of board committees in NZ firms. Given the NZX requirement (introduced in 2003) that firms listing on the main board must have a separate audit committee, it is unsurprising that the percentage of firms with such a committee rose from 59.8 in 1995 to 95.7 in 2010. Audit committees have also become increasingly dominated by independent directors, their representation rising from $68.1 \%$ on average in 1995 to $80.4 \%$ in 2010 . In this context, interestingly, the NZX listing rules specify only that the audit committee contain a simple majority of independent directors, so NZ firms appear to have voluntarily adopted structures over and above requirements. ${ }^{11}$ Similarly, even without the impetus of a listing rule, the proportion of firms operating a separate remuneration committee more than doubled - from $34.9 \%$ to $79.3 \%$ - during

\footnotetext{
${ }^{10}$ Sarkar and Sarkar (2009) estimate the mean number of directorships per Indian director in 2003 to be 5.49 , but it is unclear whether they include unlisted firms in their calculations.

${ }^{11}$ Bradbury et al. (2006) report evidence suggesting that audit committees are effective only when all members are independent directors.
} 
Table 6: Board Committees

Comparison of 1995 and 2010 statistics for board committee characteristics. Variable definitions and sample sizes appear in Table 1. Terms in parentheses underneath the variable names indicate the sample sizes for 1995 and 2010 respectively. The $t$-test is used to evaluate differences in sample means; the W (Wilcoxon)-test is used to evaluate differences in sample medians; the Binomial test is based on a $z$-statistic and is used to evaluate differences in sample proportions; the Size-adjusted $t$-test extends the standard $t$ and Binomial tests by controlling for firm size in an OLS regression. ${ }^{* * *}\left({ }^{* *}\right)\left(^{*}\right)$ denotes statistical significance at the $1 \%(5 \%)(10 \%)$ level.

\begin{tabular}{|c|c|c|c|c|c|}
\hline Variable & $\begin{array}{c}1995 \\
\text { Mean or \% } \\
\text { (Median) }\end{array}$ & $\begin{array}{c}2010 \\
\text { Mean or \% } \\
\text { (Median) }\end{array}$ & $\begin{array}{c}t \text {-test } \\
(\mathrm{W} \text {-test })\end{array}$ & $\begin{array}{l}\text { Binomial } \\
\text { test }\end{array}$ & $\begin{array}{l}\text { Size-adjusted } \\
t \text {-test }\end{array}$ \\
\hline $\begin{array}{l}\text { Audit Committee } \\
(86,117)\end{array}$ & $59.8 \%$ & $95.7 \%$ & & $* * *$ & $* * *$ \\
\hline $\begin{array}{l}\text { Remuneration Committee } \\
(86,117)\end{array}$ & $34.9 \%$ & $79.3 \%$ & & $* * *$ & $* * *$ \\
\hline $\begin{array}{l}\text { Audit Committee } \\
\text { Independence } \\
(52,109)\end{array}$ & $\begin{array}{c}0.681 \\
(0.667)\end{array}$ & $\begin{array}{c}0.804 \\
(0.750)\end{array}$ & $\begin{array}{c}* * * \\
(* * *)\end{array}$ & & $* * *$ \\
\hline $\begin{array}{l}\text { Remuneration Committee } \\
\text { Independence } \\
(31,88)\end{array}$ & $\begin{array}{c}0.726 \\
(0.667)\end{array}$ & $\begin{array}{c}0.747 \\
(0.750)\end{array}$ & & & \\
\hline
\end{tabular}

the sample period, although independent director representation remained unchanged at a little over $70 \%$ in the average firm.

These figures are slightly below those in the usual comparator countries. For example, Henry (2010) finds that, as of 2002, 99\% of Australian listed firms had a separate audit committee and $88 \%$ a separate remuneration committee. For the US, Chhaochharia and Grinstein (2007) report that $100 \%$ of listed firms had a separate audit committee in 2003, with $99 \%$ also having a separate remuneration committee. Neither study provides details on independent director representation on these committees, but Chhaochharia and Grinstein record that $76.8 \%$ of US firms had audit committees comprising entirely of independent directors in 2003, so even if none of the remaining boards had an independent majority the overall independent director representation would still be in the vicinity of 85-90\% - somewhat higher than the corresponding NZ figure noted above.

\subsubsection{CEO Board and Committee Involvement}

CEO involvement in NZ boards changed little during the sample period. However, some of these static levels of involvement differ markedly from what happens in other countries. In their discussion of international governance trends, LeBlanc and Gillies (2005, p92) claim that:

It is almost unheard of for the chief executive officer of the corporation not to be a member of the board of directors. Indeed, in many companies, particularly in the United States, it is not unusual for the role of the board and CEO to 
Table 7: CEO Board and Committee Involvement

Comparison of 1995 and 2010 statistics for CEO involvement on the board of directors. Variable definitions and sample sizes appear in Table 1. Terms in parentheses underneath the variable names indicate the sample sizes for 1995 and 2010 respectively. None of the differences between 1995 and 2010 are statistically significant at conventional levels.

\begin{tabular}{lcc}
\hline & 1995 & 2010 \\
Variable & $\%$ & $\%$ \\
\hline $\begin{array}{l}\text { CEO-Chair } \\
(86,117)\end{array}$ & $1.1 \%$ & $0.0 \%$ \\
$\begin{array}{l}\text { CEO on Board } \\
(86,117)\end{array}$ & $64.0 \%$ & $66.7 \%$ \\
$\begin{array}{l}\text { CEO on Audit Committee } \\
(86,117)\end{array}$ & $10.0 \%$ & $7.4 \%$ \\
$\begin{array}{l}\text { CEO on Remuneration Committee } \\
(86,117)\end{array}$ & $6.7 \%$ & $10.1 \%$ \\
\hline \hline
\end{tabular}

be combined.

Neither statement holds in NZ. As Table 7 shows, virtually no NZ CEO simultaneously filled the role of board chair in either 1995 or 2010. By contrast, Bhagat and Bolton (2010), Brick and Chidambaran (2010), and Chhaochharia and Grinstein (2007) all report 60-70\% of US firms as having combined CEO-Chair roles in the 2000s, while Henry (2010) finds a corresponding range of $21-25 \%$ in Australia during the same period. Similarly, far from being "almost unheard of", approximately $1 / 3$ of NZ CEOs do not sit on their company's board.

At the other end of the spectrum, CEO membership of the remuneration committee is relatively common in NZ firms, with $10.1 \%$ having this characteristic in 2010. By contrast, Vafeas (2003) reports that only two of the 271 largest firms in the Forbes compensation survey for 1997 fall into this category. Similarly, Anderson and Bizjak (2003, p1325) note that by 1998 insiders "are essentially absent" from a random sample of 110 New York Stock Exchange firms.

\section{$3.2 \quad 1995-2010$ Trends in Board Characteristics}

We now address the extent to which the observed differences (or non-differences, as the case may be) between 1995 and 2010 reflect consistent trends throughout the sample period. To do so, we graphically depict the board characteristic values for each of the four sample years. In order not to overload the reader with pictures, we focus on ten characteristics we view as being the most important and/or interesting.

Figure 1 displays the results of this exercise. The level of chair and director fees, the representation of independent and female directors, and the existence of audit and remuneration committees all increased monotonically over the period. Somewhat surprisingly however, virtually none of the increases in committee existence and independent director representation occurred between 2000 and 2007, despite this being the period spanning the 

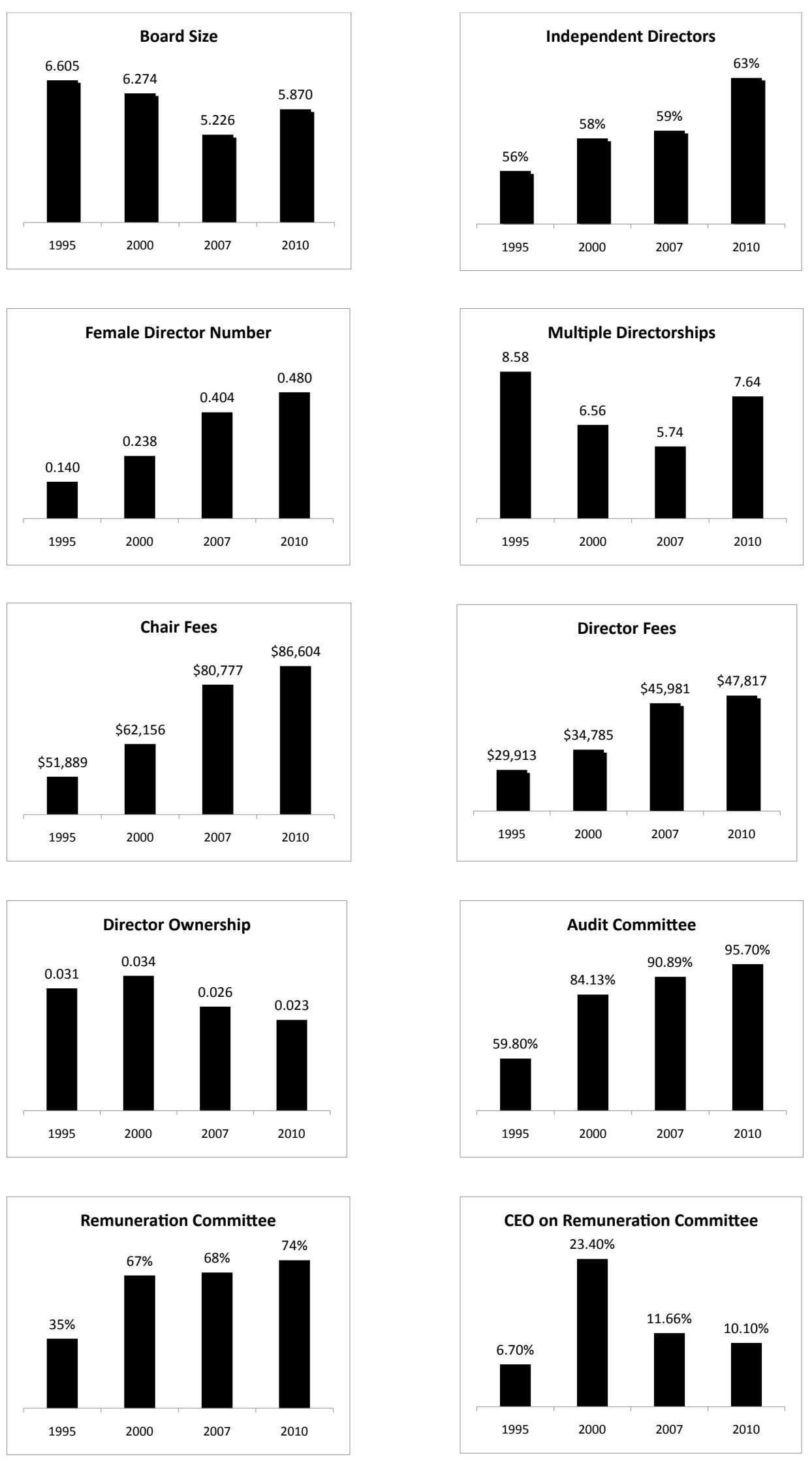

Figure 1: 1995-2010 Trends in Board Composition, Activity, and Incentives: All Firms Combined. 
introduction of NZX rules and recommendations regarding these characteristics. In the cases of the audit and remuneration committees, for example, by far the greatest rate of formation occurred prior to 2000, suggesting that the NZX initiatives were simply formalising phenomena that were already occurring naturally. By contrast, the biggest increases in chair and director fees took place during the 2000-2007 period, a somewhat unexpected consequence of a greater official focus on governance matters.

The number of directors per board, the number of directorships per director, and average director share ownership trended down during the fifteen year period, but not monotonically. The first two both fell sharply between 1995 and 2007 before rebounding somewhat in 2010. Whether this represents the beginning of a return to the past or is simply a statistical blip remains to be seen. Director share ownership actually rose slightly between 1995 and 2000 before falling sharply in the following ten years. Again, this is probably not the outcome envisaged by the NZX governance initiatives.

\section{Other Issues}

\subsection{Board Trends and Firm Size}

The results presented thus far ignore possible firm size-based variation in board characteristics. To address this issue, we first place each firm-year in our sample in one of the three size categories described in section 2.2 and then re-estimate means (or percentages) in each of these categories for a selection of the variables in Table 1.

Figure 2 summarizes the results. Some board characteristics follow the same path regardless of firm size: in all three size categories, board size drifted gently downwards while the existence of audit and remuneration committees became more common. Others, however, exhibit sharply different behaviour. For example, the rate of director share ownership remained basically unchanged in small firms, but dropped noticeably in the other two categories, especially after 2000. Similarly, the average number of directorships per director rose in large firms during the sample period while falling in the other two; after starting a long way apart, by 2010 the three groups had essentially converged.

In some cases, the medium-size group showed markedly different behaviour to the other two. For instance, female board representation was initially lowest in medium-size firms, but by 2007 had risen to match that of large firms (with both some margin ahead of small firms). Similarly, CEO appointment to the remuneration committee remained largely unchanged (at 10-15\%) in the medium group, but increased sharply in large and small firms between 1995 and 2000 before tailing off to converge on the medium group's rate by 2010 .

The graphs for chair and director fees are revealing. Not only are large firm fees considerably higher, but they also increased at a much faster rate than those of the other two (particularly compared to the small company group). Clearly, the rewards for accepting large firm directorships rose significantly in both absolute and relative terms. 

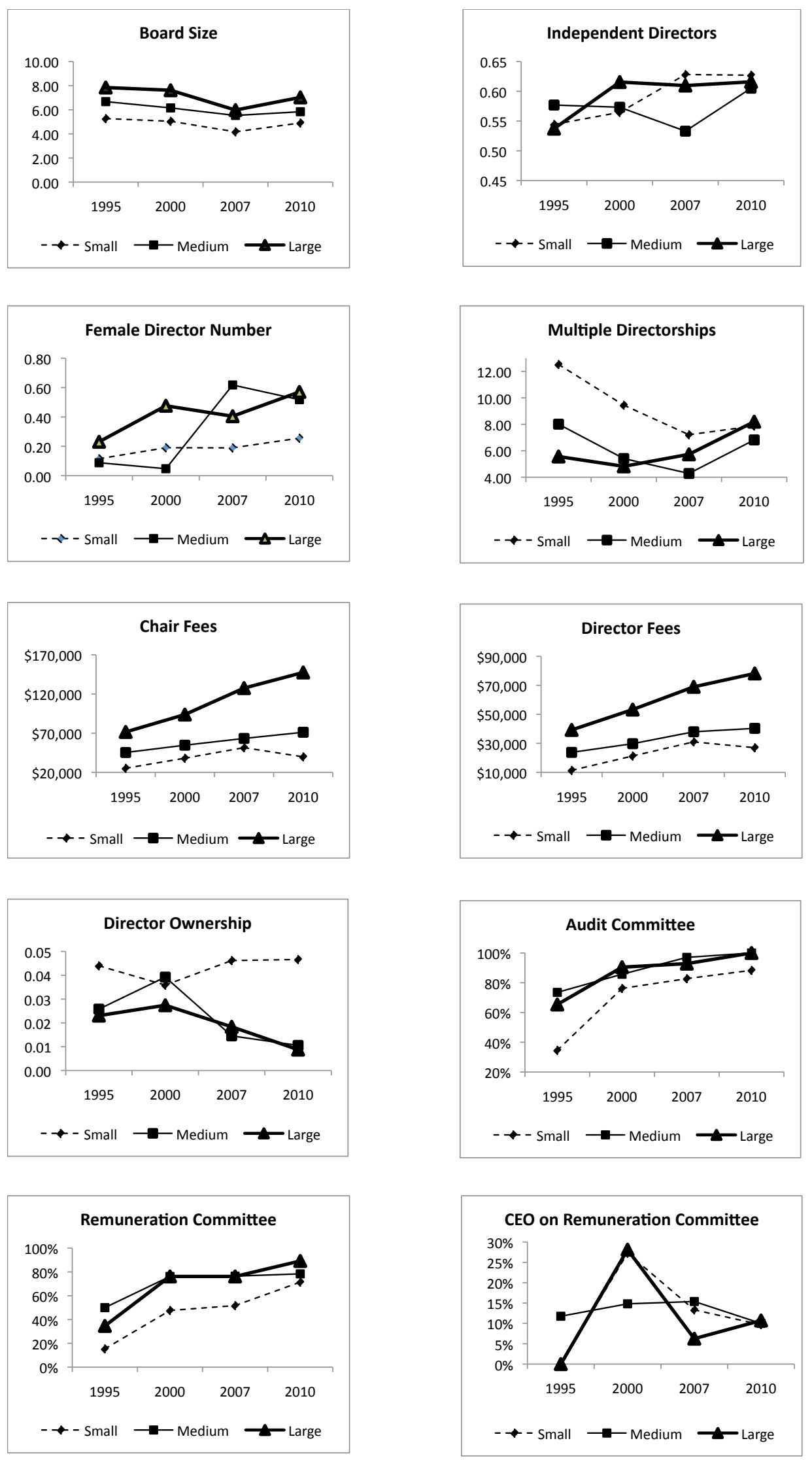

Figure 2: 1995-2010 Trends in Board Composition, Activity, and Incentives: Firm Size Groups. Small firms have total assets equal to less than $\$ 50$ million (in 2010 dollars); medium-size firms have total assets between $\$ 50$ million and $\$ 250$ million; large firms have total assets greater than $\$ 250$ million. 
Table 8: Cross-Country Differences in Board Characteristics: NZX-listed versus NZX/ASX-listed firms

\begin{tabular}{|c|c|c|c|c|}
\hline \multirow[b]{2}{*}{ Variable } & \multirow{2}{*}{$\begin{array}{l}\text { NZX only } \\
\text { Mean or } \%\end{array}$} & \multirow{2}{*}{$\begin{array}{c}\text { NZX and ASX } \\
\text { Mean or } \%\end{array}$} & \multirow{3}{*}{$t$-test } & \multirow[b]{2}{*}{ Binomial test } \\
\hline & & & & \\
\hline Non-Executive Directors & 0.830 & 0.858 & & \\
\hline Independent Directors & 0.615 & 0.704 & & \\
\hline Independent Majority & $60.6 \%$ & $75.0 \%$ & & \\
\hline Female Director Incidence & $31.7 \%$ & $50.0 \%$ & & \\
\hline Female Director Number & 0.475 & 0.500 & & \\
\hline Long-Serving Directors & 0.562 & 0.512 & & \\
\hline Board Meetings & 10.99 & 10.31 & & \\
\hline Busy Directors & $88.7 \%$ & $85.7 \%$ & & \\
\hline Remuneration Committee & $77.0 \%$ & $93.8 \%$ & & $* *$ \\
\hline $\begin{array}{l}\text { Audit Committee } \\
\text { Independence }\end{array}$ & 0.788 & 0.894 & $* *$ & \\
\hline $\begin{array}{l}\text { Remuneration Committee } \\
\text { Independence }\end{array}$ & 0.719 & 0.883 & $* * *$ & \\
\hline CEO on Board & $64.4 \%$ & $81.3 \%$ & & \\
\hline CEO on Audit Committee & $8.70 \%$ & $0.00 \%$ & & $* * *$ \\
\hline CEO on Remuneration Committee & $10.7 \%$ & $7.10 \%$ & & \\
\hline
\end{tabular}

\subsection{Cross-listing effects}

In 3.1 above, we noted some differences between NZ board characteristics and those from other (mainly much larger) countries. This raises an important question: do such differences primarily reflect something unique about NZ firms, or about the NZ governance environment? To provide some preliminary evidence on this issue, we compare the board characteristics of NZ firms listed only on the NZX with those of firms that also list on the (much larger) Australian Stock Exchange (ASX). The governance choices of such firms will be influenced by the Australian governance environment, so by comparing these choices with those of their NZX-only counterparts we can gauge the extent to which NZ board characteristics reflect the NZ governance environment. Because the ASX-listed group are typically amongst the largest NZ firms, we eschew comparison of board variables that have an obvious connection with firm size (e.g., board size, chair and director fees) in order to focus as closely as possible on 'pure' cross-listing effects. ${ }^{12}$

Table 8 reveals that differences between the two groups of firms exist primarily at the committee level. Although dual-listed firms have more independent directors, fewer busy and long-serving directors, a slightly smaller number of board meetings, and are

\footnotetext{
${ }^{12}$ We also do not consider variables where there is very little full-sample variation, e.g., CEO-Chair.
} 
Table 9: Convergence of Board Characteristics

Comparison of 1995 and 2010 standard deviations for various board characteristics. Variable definitions and sample sizes appear in Table 1. Differences are evaluated using an F-test. $* * *(* *)(*)$ denotes statistical significance at the $1 \%(5 \%)(10 \%)$ level.

\begin{tabular}{lccc}
\hline & 1995 & 2010 \\
Variable & Standard deviation & Standard deviation & F-test \\
\hline Board Size & 2.019 & 1.643 & $* *$ \\
Non-executive Directors & 0.205 & 0.155 & $* * *$ \\
Independent Directors & 0.183 & 0.198 & $* * *$ \\
Audit Committee Independence & 0.269 & 0.253 & $* .723$ \\
Remuneration Committee Independence & 0.263 & 0.726 & $*$ \\
log of Chair Fees & 0.599 & 0.043 \\
log of Director Fees & 0.558 & 0.306 \\
Director Ownership & 0.050 & 0.301 & 0.72 \\
Long Serving Directors & 0.72 & \\
\hline \hline
\end{tabular}

more likely to have at least one female director and a CEO who sits on the board, these differences are small and statistically insignificant. By contrast, the greater propensities of dual-listed firms to have (i) a remuneration committee and (ii) greater independent director representation on the audit and remuneration committees are more economically and statistically significant. Overall, however, the board choices of NZ firms do not seem to be greatly altered by listing in another jurisdiction.

\subsection{Convergence of Board Characteristics}

The adoption of very similar corporate governance codes by so many countries around the world in the last 20 years suggests the development of an international consensus on bestpractice governance, and consequently on optimal board characteristics. To the extent this is true, we would expect to see evidence of convergence in board characteristics. For example, the increasing importance placed on director independence implies that fewer boards and board committees will contain a minority of independent directors, thus reducing the dispersion in the extent to which independent directors are represented.

To examine this issue in the NZ context, we estimate standard deviations (as a proxy for dispersion) for most of the continuous variables in our sample and test for differences between 1995 and 2010. ${ }^{13}$ The results of this exercise appear in Table 9. Dispersion in the number of directors per board, the board representation of non-executive directors, and the extent of audit committee independence fell significantly between 1995 and 2010, consistent with firms moving towards an agreed 'best-practice' model of governance. In other areas, however, there is little or no sign of convergence: for independent director

\footnotetext{
${ }^{13}$ As well as eliminating the binary variables from this exercise (since standard deviations would shed little light on convergence for such variables), we also exclude variables that were close to zero in 1995 , e.g., female representation.
} 
representation on both the remuneration committee and the full board, dispersion in firm choices is unchanged during the period. Nor, after adjusting for their significant increases in mean, is there any reduction in chair and director fee dispersion - in fact, the volatility of director fees increases significantly. ${ }^{14}$

\section{$5 \quad$ Summary and Concluding Remarks}

Our principal findings in this paper are as follows:

I. Between 1995 and 2010, the average board size of NZ firms fell slightly, while the board representation of non-executive, independent and female directors all rose, as did the propensity of firms to establish separate audit and remuneration committees. Real chair and director fees rose sharply, especially in large firms.

II. By contrast, a number of board characteristics showed relatively little evidence of change over the sample period, including director share ownership, director involvement in other companies, and CEO board and committee involvement. However, these aggregate statistics conceal significant variation between different firm size groups: all of the above variables rose in some size categories while falling in others.

III. The 2003 NZX corporate governance reforms appear to have had relatively little impact on the governance choices of NZ firms: most of the change in average board characteristics occurred before 2003, while there is only weak evidence for convergence in board characteristics over the sample period.

IV. The board characteristics of NZ firms often differ quite markedly from those prevailing abroad, particularly in CEO board and committee involvement, in the frequency of board meetings, and in the number of directorships per director.

In turn, these findings reveal a number of unanswered questions about NZ boards:

(i) Why do so many NZ CEOs - approximately $1 / 3$ - not sit on their firm's board? And does this have consequences for intra-firm communication, strategy and performance?

(ii) Why do so few NZ CEOs - essentially none - serve as board chair? Is this an appropriate local response to a potential agency problem?

(iii) Relative to the typical situation overseas, a significant proportion of NZ CEOs sit on their firm's remuneration committee. Is this, as would appear at first glance, a major conflict of interest, or is it an optimal response to local conditions?

(iv) Why is the representation of independent directors on NZ boards still somewhat lower than in other countries? Is there any evidence that this hinders firm performance?

\footnotetext{
${ }^{14}$ The adjustment consists of taking the natural log of the two fees variables before estimating their standard deviations, which is approximately equivalent to estimating the coefficient of variation of the unlogged variables.
} 
(v) Why do NZ boards tend to hold more meetings than their overseas counterparts? Is this an indicator of greater diligence or greater inefficiency?

(vi) Does the relatively large number of directorships held by NZ directors dilute their effectiveness? Does it lead to individual director shirking by, for example, the avoidance of chair and committee appointments?

(vii) How and why have NZ chair and director fees risen so markedly over the 15-year period of our study? Does this primarily reflect rent expropriation by boards, or increasing international competition for director talent, or compensation for increased risks and responsibilities?

We hope that at least some of these questions thrown up by our data will motivate further research on NZ corporate boards. 


\section{References}

Adams, R. and D. Ferreira, 2009. Women in the boardroom and their impact on governance and performance. Journal of Financial Economics 94, 291-309.

Adams, R., B Hermalin and M. Weisbach, 2010. The role of boards of directors in corporate governance: a conceptual framework and survey. Journal of Economic Literature 48, 59-108.

Agrawal, A. and C. Knoebe, 1996. Firm performance and mechanisms to control agency problems between managers and shareholders. Journal of Financial and Quantitative Analysis, 31, 377-397.

Al-Najjar, B., 2010. The determinants of the frequency of board meetings: evidence from categorical analysis. Journal of Applied Accounting Research, forthcoming.

Anderson, R. and J. Bizjak, 2003. An empirical examination of the role of the CEO and the compensation committee in structuring executive pay. Journal of Banking and Finance 27, 1323-1348.

Andjelkovic, A., G. Boyle and W. McNoe, 2002. Public disclosure of executive compensation: do shareholders need to know? Pacific-Basin Finance Journal 10, 97-117.

Barnhart, S. and S. Rosenstein, 1998. Board composition, managerial ownership, and firm performance: an empirical analysis. Financial Review 33, 1-16.

Bebchuk, L. and J. Fried, 2004. Pay without Performance: The Unfulfilled Promise of Executive Compensation. Cambridge: Harvard University Press.

Becht, M., P. Bolton and A. Röell, 2003. Corporate governance and control. Handbook of Economics and Finance (ch. 1), eds. G. Constanides, M. Harris and R. Stulz. Elsevier B.V.

Bhagat, S. and B. Black, 2002. The non-correlation between board independence and long-term firm performance. Journal of Corporation Law 27, 231-274.

Bhagat, S. and B. Bolton, 2010. Director ownership, governance and performance. Available at SSRN: http://ssrn.com/abstract $=1571323$

Bhagat, S., D. Carey and C. Elson, 1999. Director ownership, corporate performance, and management turnover. The Business Lawyer 54, 585.

Bradbury, M., Y. Mak and S. Tan, 2006. Board characteristics, audit committee characteristics and abnormal accruals. Pacific Accounting Review 18, 47-68.

Brick, I. and N. Chidambaran, 2010. Board meetings, committee structure, and firm value. Journal of Corporate Finance 16, 533-553. 
Brick, I., O. Palmon and J. Wald, 2006. CEO compensation, director compensation and firm performance: evidence of cronyism? Journal of Corporate Finance 12, 403-423.

Brickley, J., J. Coles and G. Jarrell, 1997. Leadership structure: separating the CEO and chairman of the board. Journal of Corporate Finance 3, 189-220.

Byrd, J. and K. Hickman, 1992. Do outside directors monitor managers? Evidence from tender offer bids. Journal of Financial Economics, 32, 195-221.

Cahan, S., F. Chua and R. Nyamori, 2005. Board structure and executive compensation in the public sector: New Zealand evidence. Financial Accountability and Management $21,437-465$.

Cahan, S. and B. Wilkinson, 1999. Board composition and regulatory change: evidence from the enactment of new companies legislation in New Zealand. Financial Management $28,32-42$.

Chhaochharia, V. and Y. Grinstein, 2007. The changing structure of US corporate boards: 1997-2003. Corporate Governance: An International Review 15, 1215-1223.

Chin, T., E. Vos and Q. Casey, 2004. Levels of ownership structure, board composition and board size seem unimportant in New Zealand. Corporate Ownership and Control $2,119-128$.

Clarke, T., 2007. International Corporate Governance. UK: Routledge.

Coles, J., N. Daniel and L. Naveen, 2007. Boards: does one size fit all? Journal of Financial Economics, 87, 329-356.

Cordeiro, J., R. Veliyath and E. Erasmus, 2000. An empirical investigation of the determinants of outside director compensation. Corporate Governance: An International Review 8, 268-279.

Dann, L., D. Del Guercio and M. Partch, 2003. Governance and boards of directors in closed-end investment companies. Journal of Financial Economics 69, 111-152.

Elayan, F., T. Meyer and J. Lau, 2003. Executive incentive compensation schemes and their impact on corporate performance: evidence from New Zealand since legal disclosure requirements become effective. Studies in Economics and Finance 21, $54-92$.

Fama, E. and M. Jensen, 1983. Separation of ownership and control. Journal of Law and Economics 26, 301-326.

Farrer, J. and I. Ramsay, 1998. Director share ownership and corporate performance evidence from Australia. Corporate Governance: An International Review 6, 233248. 
Fich, E. and A. Shivdasani, 2006. Are busy boards effective monitors? Journal of Finance $61,689-724$.

Ferris, S., M. Jagannathan, and A. Pritchard, 2003. Too busy to mind the business? Monitoring by directors with multiple board appointments. Journal of Finance 58, 1087-1111.

Fox, M., 1996. Board structure of New Zealand listed companies: an international comparative study. Lincoln University, Department of Economics and Marketing Discussion Per No. 20.

Francoeur, C., R. Labelle and B. Sinclair-Desgagne, 2007. Gender diversity in corporate governance and top management. Journal of Business Ethics 81, 83-95.

Gillan, S., 2006. Recent developments in corporate governance: an overview. Journal of Corporate Finance 12, 381-402.

Guest, P., 2009. The impact of board size on firm performance: evidence from the UK. European Journal of Finance 15, 385-404.

Henry, D., 2010. Agency costs, ownership structure and corporate governance compliance: a private contracting perspective. Pacific-Basin Finance Journal 18, 24-46.

Honeine, S. and P. Swan, 2010. Is company performance dependent on outside director 'skin in the game?' Available at SSRN: http://ssrn.com/abstract=1746536.

Hurst, S. and E. Vos, 2009. New Zealand CEO compensation factors. Corporate Ownership and Control 6, 47-53.

Hossain, M., A. Prevost and R. Rao, 2001. Corporate governance in New Zealand: the effect of the 1993 Companies Act on the relation between board composition and firm performance. Pacific-Basin Finance Journal 9, 119-145.

Jiang, H., A. Habib and C. Smallman, 2009. The effect of ownership concentration on CEO compensation-firm performance relationship in New Zealand. Pacific Accounting Review 21, 104-131.

Kang, H., M. Chang and S. Gray, 2007. Corporate governance and board composition: diversity and independence of Australian boards. Corporate Governance: An International Review 15, 194-207.

Kesner, I., 1988. Directors' characteristics and committee membership: an investigation of type, occupation, tenure and gender. Academy of Management Journal 31, 66-84.

Kiel, G. and G. Nicholson, 2006. Multiple directorships and corporate performance in Australian listed companies. Corporate Governance: An International Review 14, $530-546$. 
Klein, A., 2002. Audit committee, board of director characteristics, and earnings management. Journal of Accounting and Economics 33, 375-400.

Leblanc R. and J. Gillies, 2005. Inside The Boardroom. Canada: John Wiley \& Sons.

Linn, S. and D. Park, 2005. Outside director compensation policy and the investment opportunity set. Journal of Corporate Finance 11, 680-715.

Mak, Y. and Y. Kusnadi, 2005. Size really matters: further evidence on the negative relationship between board size and firm value. Pacific-Basin Finance Journal 13, $301-318$.

Mak, Y. and M. Roush, 2000. Factors affecting the characteristics of boards of directors: an empirical study of New Zealand initial public offering firms. Journal of Business Research 47, 147-159.

Marsden, A. and A. Prevost, 2005. Derivatives use, corporate governance, and legislative change: an empirical analysis of New Zealand listed companies. Journal of Business Finance and Accounting 32, 255-289.

Muth, M. and L. Donaldson, 1998. Stewardship theory and board structure: a contingency approach. Corporate Governance: An International Review 6, 5-28.

Ning, Y., W. Davidson, and J. Wang, 2010. Does optimal corporate board size exist? An empirical analysis. Journal of Applied Finance 20, 57-69.

Prevost, A., R. Rao and M. Hossain, 2002. Determinants of board composition in New Zealand: a simultaneous equations approach. Journal of Empirical Finance 9, 373397.

Radio NZ, 2011. Australia boosts women director numbers faster than NZ. http://www.radionz.co.nz/news/business/74188/australia-boosts-women-director-numbersfaster-than-nz

Rainsbury, E., M. Bradbury and S. Cahan, 2008. Firm characteristics and audit committees complying with 'best practice' membership guidelines. Accounting and Business Research 38, 393-408.

Rainsbury, E., M. Bradbury and S. Cahan, 2009. The impact of audit committee quality on financial reporting quality and audit fees. Journal of Contemporary Accounting and Economics 5, 20-33.

Reddy, K., S. Locke and F. Scrimgeour, 2010. The efficacy of principle-based corporate governance practices and firm financial performance. International Journal of Managerial Finance 6, 190-216. 
Reddy, K., S. Locke, F. Scrimgeour and A. Gunasekarage, 2008. Corporate governance practices of small cap companies and their financial performance: an empirical study in New Zealand. International Journal of Business Governance and Ethics 4, 51-78.

Ryan, H., and R. Wiggins, 2004. Who is in whose pocket? Director compensation, bargaining power, and board independence. Journal of Financial Economics 73, 497-524.

Sarkar, J. and S. Sarkar, 2009. Multiple board appointments and firm performance in emerging economies: evidence from India. Pacific-Basin Finance Journal 17, 271293.

Simpson, W., D. Carter and F. D'Souza, 2010. What do we know about women on boards? Journal of Applied Finance 20, 27-39.

Vafeas, N. 1999. Board meeting frequency and firm performance. Journal of Financial Economics 53, 113-142.

Vafeas, N., 2003. Length of board tenure and outside director independence. Journal of Business Finance and Accounting 30, 1043-1064.

Van Ness, R., P. Miesing, and J. Kang, 2010. Board of director composition and financial performance in a Sarbanes-Oxley world. Academy of Business and Economics Journal 10, 56-74.

Yermack, D., 1996. Higher market valuation of firms with a small board of directors. Journal of Financial Economics 40, 185-211.

Zhang,Y., J. Zhou and N. Zhou, 2007. Audit committee quality, auditor independence, and internal control weakness. Journal of Accounting and Public Policy 26, 300-327. 